\title{
THE IMPORTANCE OF IMPROVING THE COMPETENCE OF EMPLOYEES IN THE 21ST CENTURY
}

\author{
INETA LAKSTIGALA \\ SIGNE BALINA
}

\begin{abstract}
In the era of globalisation and the development of information technologies, increased attention is being paid to the development of workers' competences. The aim of competence is a set of attitudes and behaviour which strengthens the relationship between the institutions and employees, focusing mainly on professional, motivated, flexible and honest employees of the public administration. It is important to work and strengthen personal and professional competences. This means that there is a need to regularly assess the competencies of public administration employees in order to improve them and understand which competencies will be required today. In order to improve the quality, efficiency, development of creative thinking, knowledge and adaptation to developments and requirements of the $21^{\text {st }}$ century, there is a regular need to improve personal and professional competences. As well, it must be prepared that new jobs will be created in the future, where new skills and knowledge will be needed. It is therefore important to focus on the development of new skills throughout life in the learning process, which will produce good results for career development in order to become a competitive and competent employee. The aim of the study is to find out what employees' competencies will be most demanding in the future. The methods used by the study are document analysis and methods of quantitative data analysis. The results of the study are used in practice in improving and assessing the development and necessity of the competence of public administration employees.
\end{abstract}

Keywords: Latvia, development, personnel development, competencies

JEL code: O15, J24, M59

\section{INTRODUCTION}

Increasing attention is being paid to the appropriate competence of public administration employees, to education gained and to self-motivation to develop regularly in order to perform their duties with experienced, knowledgeable specialists seeking to achieve the objectives and tasks pursued by the institution. It is necessary to define strictly what competences are and will be needed for each individual of the institution in the future, how they will be developed and evaluated. Staff competencies should be regularly taken to avoid skills 
mismatches and job productivity reductions in a timely manner. And inspire regular visits to training establishments aimed at improving professional and personal competence. As a result of the development of regular competence, staff will adapt and acquire future skills and will be flexible in adapting to any innovation, prepared and open to additional responsibilities in acquiring professional experience. Identifying the need for the development of the expertise of each specialist and effectively identifying the direction of learning development by assessing its usefulness.

\section{ROLE OF COMPETENCE AT WORK}

In order to work in the professional field, to develop knowledge, to take responsibility, to plan and to pursue development, there must be a competence (Perrenoud, 2004). It is therefore important to determine what powers will be required in the performance of the post. Professional competence is the capacity, working in the professional field, personally planning and assuming responsibility (Bader, 1990). Professional competence shall be acquired with qualifications in a particular speciality and the knowledge acquired shall be applied in practice. In the 1990s, competence was described as being acquired in the educational process, based on acquired knowledge and attitudes (Stabins, 1998). People's competence can be discussed if a person is able to safely and successfully realise his or her intentions when a person has the knowledge and skills to deal with problems and challenges, and if a person is able to plan his or her activities in different situations (Tilla, 2005). This means that in working education must be closely linked to a speciality and be interested in the chosen profession. Although there are people who learn about doctors, the auto mechanic profession is a good thing to do. In the opinion of T. Koke (1999), competence is the result of learning where competencies are linked to skills based on acquired knowledge. When a person likes what he or she is doing, then the productivity of work is improving, the person tends to constantly learn something new, to develop knowledge, to gain satisfaction from the work he has done. In the process of work, it is important to be satisfied with the work done, not to fulfil the tasks of work, just because they need to be done. Competence can only be gained in action by learning or working (Melton, 1997).

Scientist F. Orthey (Orthey, 2002) considers the concept of competence as a means of achieving better and better quality work and, in order to achieve personal objectives. Given that the work of public administration involves people - team work, customers and colleagues - there needs to be good communication and cooperation skills. The person must be open, the ability to adapt to the other person, the ability to listen and listen to other opinions, and to express his or her thoughts. The working relationship depends on human attitudes and behaviour and the quality of the workplace (Kalleberg, Reskin, Hudson, 2000). Building a relationship and tackling conflict is a social 
competence where a person is focused on creating and strengthening social interaction (Barblett \& Maloney, 2011). Working with people is not connected with silence and avoidance of any communication. Competence takes the form of human action, attitudes and thinking, with long-term effects or determination of behaviour (Vintisa, 2004).

The Spencer Competencies were defined as the basic characterisation of the individual associated with the highest achievement in the working situation (Spencer, Spencer, 1993). Appropriate competences have the potential to achieve objectives and growth opportunities. The main competences of the national administration are: the competence of interpersonal effectiveness, tasks and processes management, personal effectiveness competencies, managerial competence, organisation understanding and value-acceptance competencies and thinking and problem-solving competencies (Competencies dictionary, 2011). However, the European list of basic principles on key competences for lifelong learning includes the following key competences: literacy, language competence, science, technological, engineering and mathematical competence, digital competence, personal, social and learning competence, civil competence, business competence and cultural awareness and expression competences (European Commission, 2018).

The important factor for the development of human competence is human interests and priorities, if a person likes and interests in his or her specialty, then he or she will be developed. This means that each person's choice for the development of competence is based on the importance of individual values. The person personally evaluates what will be achieved when attending training, how important they are, and whether there is a desire to learn something. If a person works only to get a salary or to have a job, such a person is not motivated to improve him or herself. Today, a flexible, versatile, self-motivated and inquisitive person is allowed to experience and succeed in career growth. Because such a person is open to innovation and is in a continuous rhythm of capacity development. These days, it is very important that the way human thinking is adapted and adopted today's spotlights.

\section{DEVELOPMENT OF THE COMPETENCE OF EMPLOYEES}

The development of the competence of employees shall be determined after the performance of the work of employees of the annual State Administration, specifying which competencies are needed to be improved. Appropriate training shall be identified for the development of competence. But the course visit has a certain number of visits because it depends on the institution's budget resources that are invested in personnel training. Public administrations are interested in learning something new and improving professional and personal skills. Employees' attitudes to attending, acquiring and using training (seminars, courses, conferences) are equally important. If a person goes to 
attend training with great interest, there is a probability that the employee will be actively involved in the training process and will be interested in attending and listening to the course until the end and a lot of it will be beneficial. The public administration is interested in investing financial resources to achieve the objective and good job results, so regularly organises the training of employees and, as far as possible, supports the attendance of different educational establishments. If a worker visits training visits as an obligation to obtain a certificate and without getting anything new and interesting, attending those training is a disadvantage for the institution. It is therefore important to find out how useful training has been, whether it has been achieved by visitors and how valuable this learning process has been. Therefore, a test should be carried out before the certificate is issued, which will also reflect how carefully and with what interest the training was attended.

The development of competence may not only be determined on the basis of an assessment of the performance of each employee's work, but on the one hand, each member of staff shall determine what professional or personal competencies are necessary to improve. To do this, each person must be critical to himself, be familiar with his weaknesses and strengths, and develop what interferes with the work process. In order to develop the necessary competences, it must be selfmotivated to work with yourself and inspire regular improvements in knowledge. Improving competence will give more opportunities for career growth, which is also, of course, a very important motivation factor for working regularly on selfempowerment. For someone to achieve something in career growth and improve the work process, he has to work with himself and his specialty needs to be heartwrenching. Then it will also be easier to force yourself to learn something new and regularly develop knowledge, expertise.

Acquiring new knowledge and improving competences is one of the tools for creating a strong culture of specialists and public administration. The majority of employees acquire knowledge and skills development through practical work, obtaining other information from customers, colleagues, providing continuous feedback. But there is something that we have not yet learned in the course of the training process to meet new acquaintances, from which you can obtain useful information and advice that would be useful at work. Because workshops are attended or studied in an educational institution where there is an opportunity to get something new, or to share your knowledge, experience, skills, ideas and advice. And of course, learning at an educational establishment or attending seminars receives a certificate that is important for raising qualifications. In order to keep employees at a continuous stage of skills and knowledge development, it is necessary to constantly motivate and offer the extensive offer of training.

F. Orthey, has listed eight competencies to be a future competent person (Orthey, 1999):

1) plurality competence: capacity to cope with complex, unsafe and minor situations, creating sufficient security in these circumstances to carry out further action; 
2) transversality competence: capacity to provide ever-increasing transitory pathways so that a reasonable conclusion can be made to a previous stage of life and to see how it can be coupled with acquiring new experience;

3) watching competence: observe themselves and others, understanding differing views and seeing preconditions that affect the development of the situation;

4) reflection competence: the ability to discern meaning and cope productively with troublesome factors;

5) socially communicable competence: capacity to analyse, shape and manage social situations;

6) the competence of the methods: the ability to model new activities and situations;

7) aesthetic competence: the ability to understand the importance of the environmental aesthetic on a daily basis; and

8) self-competence - the ability to link self-observation to the dynamic processes of the environment while maintaining balance and building the future (Orthey, 1999, 190).

For each person, competence forms in an environment in which they live and stay, it is family, friends, interests, but whether or not a person wants to develop something depends on each individual, and of course it is influenced by personal values which, over time and by different circumstances, have developed and can change. But human personal values influence the choice and desire to learn something new, to pursue opportunities for growth, to achieve a goal and to focus on development.

\section{REQUIRED COMPETENCIES FOR THE 21 ST CENTURY}

The most demanding competencies of the future that are mentioned include: strategic and innovative thinking, collaboration, creativity and critical thinking, flexibility, self-presentation skills, lifelong learning, human driving, digital skills, emotional intelligence, client orientation, skills to make decisions and address problems, communication skills, the ability to listen to different opinions, leaving on the other hand, formal enforcement, which fulfils their obligations on the basis of the rules and the performance of the work process cannot go outside the borders (see Figure 1).

A study by PayScale.com (2016) showed that recent graduates lack communication skills (Lopez, Souto, Noblejas, 2019). The office's work is increasingly moving away from huge piles of paper, strident execution, work after working time. One needs to become flexible and find their own approach to each situation. Employees must have the skills to adapt to work requirements (Ahmad, Karim, Din \& Albakari, 2013; Carnevale \& Smith, 2013). In order to adapt to the skills required by future professions, care must be taken in good time to develop 
themselves and develop staff in the institution. Digital skills (Laar, Deursen, Dijk, Haan, 2017) play an important role in meeting the skills and skills required by the $21^{\text {st }}$ century. Rapid technological development is an instrument that makes everyday access, access to information, ease work and reduce workload, work is done qualitatively. Self-made cars, drones, virtual help delivery, software translations, training by robots will replace people who are now doing these jobs: scanners are gradually replacing cashiers in supermarkets (Sousa, Rocha, 2019). Therefore, digital skills play an important role in the $21^{\text {st }}$ century, the skills of working and adapting to new technologies in order to be able to work productively and enrich the knowledge of workers with technology capabilities (Ahmad et al., 2013). Digital competences covered information management, cooperation, communication, sharing, knowledge, ethics and responsibility, evaluation and problem solving, technical operations. (Ferrari, 2012).

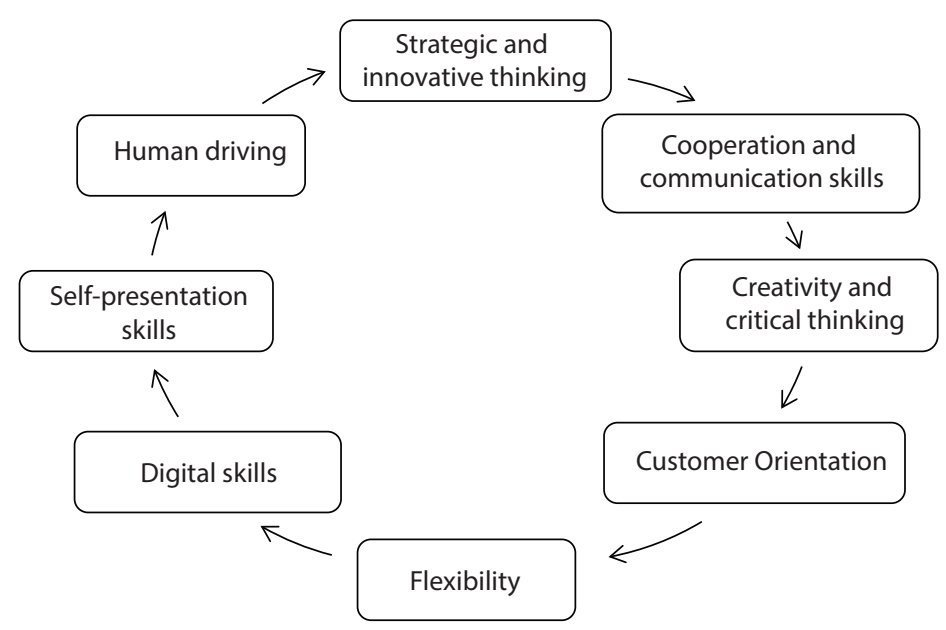

Source: prepared by the authors, on the basis of the acquired survey data.

Fig. 1. Future Competencies

Digital skills are something more than an ability to use digital sources effectively (Eshet-Alkalai, 2004). The Internet, as a resource, is unfettered, has improved quality, is able to work remotely, there is great data availability, the ability to obtain all the necessary, interested and up-to-date information. The field of information technology increasingly facilitates human learning and the use of new technology capabilities, and people are no longer able to imagine life without the Internet and modern technologies, but it is distancing people from interpersonal contact. As well, a new generation is increasingly typical of "living" in an Internet environment without interesting in what is happening around, for example, instead of playing games in a school backyard, everyone is currently sitting on their own mobile devices, thereby closing themselves out of reality. In any public place, one can see when people "live" in the Internet world and 
use the new technologies, forgetting what's going on around them. People need to be able to work not only with information technology, but also with people. People are not yet aware of the consequences that technological development may have on our skills, but the fact that technology is moving away from work and the desire to work physically hard will gradually come into contact. One cannot escape when the world's technologies of vital competence in life and work are disappearing, there is a possibility that people will no longer be able to communicate, work and work together on a team in the future, because the vast supply of technology and the Internet is remote and losing their skills to work on a team.

"The majority of Latvian residents, or $86 \%$, believe that they live in a digitally developed environment and modern technologies play an important role in improving the quality of life of each person" (Latvian residents believe they live in a digitally developed environment, 2018). The development of staff is therefore becoming more and more important today. Various training, mentoring, career development programmes, recruitment - not only financial bonuses, but also awards and team matching - are provided for the development of public administration personnel. In the LDDK survey, $96 \%$ of respondents pointed out that increasing the qualifications and continuing training of employees are very important (Latvian Employers' Confederation, 2016). The State Chancellery in 2016 implemented the European Social Fund project "The High Level Leaders Development Programme", aimed at developing the competences of senior leaders and strengthening leadership skills. Leaders should regularly develop their competences and create a good idea for subordinates that the learning process leads to the development of human competencies. National regulatory authorities are interested in developing the skills of employees, which is an essential condition for quality performance. But in order to objectively assess the competencies of employees, it is necessary to invest heavily because each employee must be assessed individually, whose competencies are linked to the duties of office. There are approximately 3300 people working in ministries (Public administration needs to change - fewer employees will not yet improve their effectiveness, 2018), which makes it difficult to control each employee individually and even to assess objectively. The assessment of the performance of employees as such is based on a subjective assessment, since it is possible to begin to assess human personality rather than professionalism in the evaluation process. It is a small border that can be easily breached, so one must be able to work by oneself and develop skills in the assessment of employees.

Knowledge is of great importance today, as are personal and professional competencies (Alvesson, 2004). In order to ensure the development of competence, financial resources are needed to ensure that institutions provide employees with training courses or seminars to increase their qualifications. The management of the Authority should be interested in working with qualified and knowledgeable specialists. The development of the competence of employees of the State 
Administration shall be the responsibility of the management of each institution which took care of the satisfaction of the employees, the raising of qualifications, the development of competence. In order to ensure that the employees of the institution are satisfied and successful in achieving the objectives and tasks pursued by the Authority, it is necessary for each employee to determine on an individual basis the training needs to be carried.

In 2018, a survey was conducted at the public administration where 119 correct questionnaires were received from 150 planned questionnaires. The purpose of the questionnaire was to clarify the competencies required for public administration employees and how the development of competence is assessed. In view of the increasing focus of compliance competence, it was clarified in which processes the assessment of competence was carried out, $82 \%$ of employees think that the workplace is subject to regular staff assessment, while $11 \%$ of employees consider it to be in recruitment, recruitment or promotion, while $6 \%$ are planning training, $1 \%$ and change in pay but $1 \%$ not informed (see Table 1 ).

Table 1

Determination of competence at work

\begin{tabular}{|l|c|}
\hline $\begin{array}{l}\text { In which personnel management processes will your competence at work } \\
\text { be determined/evaluated? }\end{array}$ & Result \% \\
\hline Recruitment: recruitment or recruitment & $11 \%$ \\
\hline Regular staff assessment is carried out at the workplace & $82 \%$ \\
\hline Planning worker training & $6 \%$ \\
\hline Changing the size of the rewards & $1 \%$ \\
\hline I don't know, I'm not aware of personnel management processes & $0 \%$ \\
\hline
\end{tabular}

Source: prepared by the authors, on the basis of the acquired survey data.

The assessment of competence shall take place in any process, including the annual evaluation of the performance of the work of employees, which shall assess whether employees need to develop knowledge and what competencies need to be improved. Today, more and more people are seeking to use new technologies to reduce administrative burdens, so the need for new knowledge, new skills and development orientation is becoming increasingly necessary. But knowledge acquired through training depends on human attitudes and expectations, for example, it was found during the study that more than half did not use the learning knowledge at work (see Figure 2). In principle, there are a number of reasons why the acquired knowledge and skills are not used at work:

- possible training which is not closely related to the speciality;

- create new training programmes in line with today's requirements;

- learning knowledge and skills depends on the expectations and interests of the employee - attitudes. 


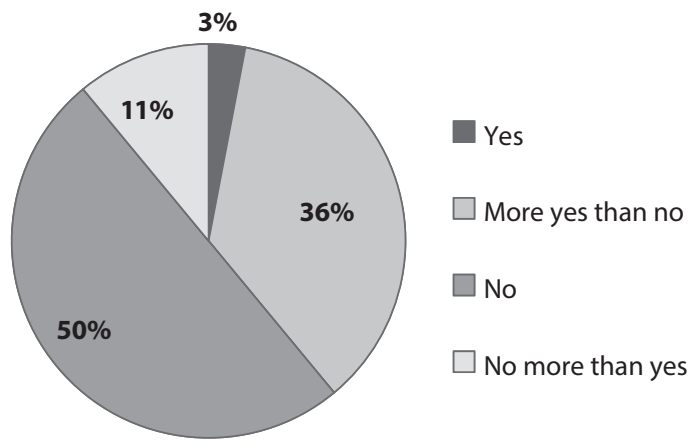

Source: prepared by the authors, on the basis of the acquired survey data.

Fig. 2. Do you use knowledge and skills in the learning process at work?

The experience of human work plays an important role when recruiting, not only demands for work experience, skills, but also acquired education are raised. At the time of removal, it was established whether job experience was needed in the candidature, then $94 \%$ replied that it was necessary, but only $6 \%$ believed it was not necessary (see Figure 3).

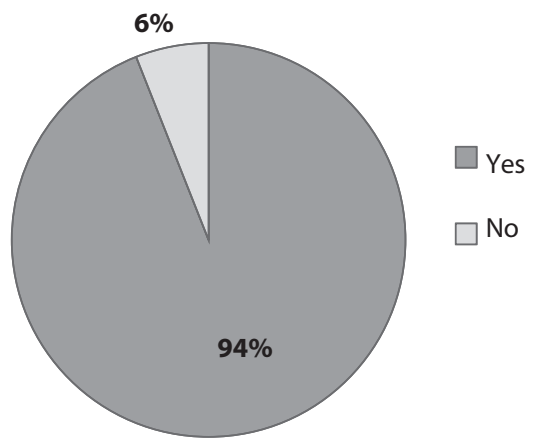

Source: prepared by the authors, on the basis of the acquired survey data.

Fig. 3. Is there a need for experience in canvassing for a specific post?

Human working experience plays a key role when recruiting a worker is important in the experience of work, education, expertise in a particular specialty, language knowledge, skills to work with computer programs and systems, language knowledge. For example, all those surveyed consider that there is a need for experience in a particular sector or field in which the institution operates. Of course, it is not always possible to rely on the education and experience gained, so it is good to organise interviews that need to be critical, and to find out the specific issues and whether a person as a personality will be relevant to that post.

In the questionnaire process, it was found that knowledge, acquired education and experience played a key role in the work, as $74 \%$ pointed out that it was 
important for the public administration to have a master's degree. $23 \%$ believe that bachelor's degree and 3\% doctoral education are sufficient (see Figure 4).

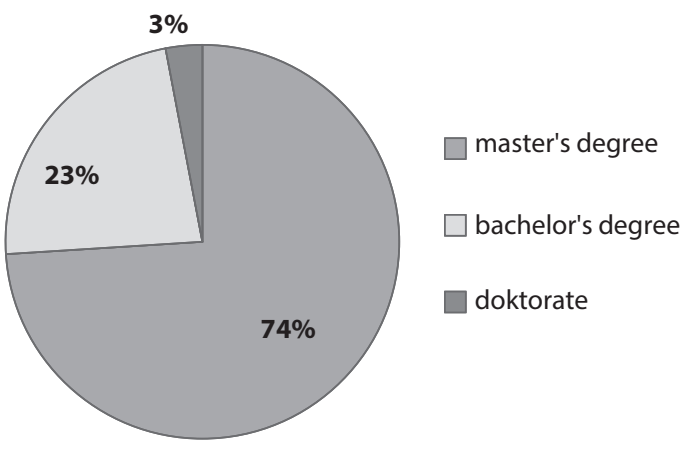

Source: prepared by the authors, on the basis of the acquired survey data.

Fig. 4. How does education be required when working in public administration?

As part of the questionnaire, the authors found what the five key competences are, which need to be further developed today:

1) communication and cooperation skills;

2) management skills;

3) creative thinking;

4) digital skills;

5) flexibility.

Communication and cooperation skills are first to show that people still have important interpersonal relations in the working process. Then, of course, leadership demands, creative thinking, and only a fourth place is digital literacy. This means that people are gradually moving towards the need to develop digital skills to match today's trends. Although there is virtually no need for digital skills in public administrations because of computer and document work. But using the new technology capabilities puts pressure on the circulation of electronic documents, with the aim of minimising the circulation of a paper document or abandoning it entirely, ensuring that documents are archived under pressure of one button. Therefore, it cannot be argued that there is no change in public administration. Similarly, conferences and seminars on artificial intelligence underpinning digital skills are increasingly being organised. But the fifth place ranks the skill of being flexible, adapting to any situation. In the $21^{\text {st }}$ century, it is important that a person is in continuous development, learning the opportunities of new technology that would facilitate the work process, such as digital skills, as an assistant to each employee's major responsibilities, and which is one of the skills required by the $21^{\text {st }}$ century, will of course be even more demanding in the future. But developing skills is not only to improve the work process but to improve personal and professional growth. 
Training aims to provide the necessary expertise to build or refresh skills to organise work, to improve the level of skills and competences, to promote positive communication between staff, assessment of stress situations, identification of business growth opportunities, development for success and the development and identification of new competences. It is therefore important to develop competences on a regular basis, to be open to innovation and not to stop oneself with skills that are today outdated, typical for older people. For example, if a foreign language has not been used for some time, then without even knowing it, the person is forgetting it gradually. In order not to happen, it should be used regularly when communicating, reading, learning, or writing. But there must be a desire to maintain or improve skills, so they will not disappear. And today, the rapid development of technology forces the regular development of expertise.

\section{CONCLUSIONS, PROPOSALS} that:

On the basis of the literature analysis and the study carried out, it is concluded

1. Educational institutions which provide training for employees of a State institution shall be familiar with the objectives of the activities of these institutions and the necessary competencies of the employees for the purposes of the development system. It would then be easier to offer development training programmes to employees.

2. Human competence is formed in the family, in the environment in which people live, affects friends or acquaintances, personal interests, educational and life objectives acquired. Skills needs to be developed throughout their lives by restoring and improving new skills, knowledge and skills in their profession, so $74 \%$ have indicated that there is an important degree in public administration, while $94 \%$ have indicated that work experience is important.

3. The rapid technological developments of the $21^{\text {st }}$ century play a key role in the development of digital skills, which enhances the quality of work and facilitates the execution of complex works. But the work process places emphasis not only on digital skills, but on communication skills, leadership skills, creative thinking and flexibility, thus adapting to today's demand for future skills.

During the working period, the following proposals were put forward:

1. High attention must be paid to the self-motivation of drivers and to the need to learn new knowledge and to regularly take care of skills and inspire those who have succumbed to the development of skills and professional development. Not only to visit educational establishments and conferences for the development of competence, but to take advantage of the opportunity to learn in the digital environment.

2. It is important for the staff responsible of the institutions to regularly compile data and carry out an analysis to identify the usefulness of the learning process 
and to identify what is needed to improve the training process and to motivate workers to improve their competencies.

3. In terms of today's global development, it should not be forgotten that the employee should regularly develop all the skills needed for work, rather than focusing solely on the need for the most advanced and popular skills of today, work with all personal and professional skills, so it is important to assess what training will be useful for the needs of work. There is also an important attitude towards new technologies and a desire to acquire new skills.

\section{REFERENCES}

Ahmad, M., Karim, A. A., Din, R., \& Albakri, I. S. M. A. (2013). Assessing ICT competencies among postgraduate students based on the $21^{\text {st }}$ century ICT competency model. Asian Social Science, 9(16), 32e39.

Alvesson, M. (2004). Knowledge Work and Knowledge - Intensive Firms. Oxford university press - Oxford.

Barblett, L., \& Maloney, C. (2011). Complexities of Assessing Social and Emotional Competence and Wellbeing in Young Children. Australian Journal of Early Childhood, 35(2), 12-18.

Carnevale, A. P., \& Smith, N. (2013). Workplace basics: The skills employees need and employers want. Human Resource Development International, 16(5), $491 \mathrm{e} 501$. http://dx.doi.org/10.1080/13678868.2013.821267.

Eshet-Alkalai, Y. (2004). Digital literacy: A conceptual framework for survival skills in the digital era. Journal of Educational Multimedia \& Hypermedia, 13(1), 93e107.

European Commission (2018). COMMISSION STAFF WORKING DOCUMENT Accompanying the document. Proposal for a COUNCIL RECOMMENDATION on Key Competences for Lifelong Learning $\{\operatorname{COM}(2018) 24$ final $\}$. Brussels, 17.1.2018, SWD (2018) 14 final. Retrieved from: https://ec.europa.eu/education/sites/education/files/swd-recommendation-key-competences-lifelonglearning.pdf.

Ferrari, A. (2012). Digital competence in practice: An analysis of frameworks. Seville: Joint Research Centre, Institute for Prospective Technological Studies. http:// dx.doi.org/10.2791/82116.

Kalleberg, A. L., Reskin, B. F., Hudson, K. (2000). Bad jobs in America: Standard and nonstandard employment relations and job quality in the United States. American Sociological Review, 65(2), 256-278.

Competencies dictionary (2011). Retrieved from: https://www.mk.gov.lv/sites/ default/files/editor/kompetencu_vardnica.pdf_1.pdf.

Laar, E., Deursen, A. J. A. M., Dijk, J. A. G. M., Haan, J. (2017). The relation between

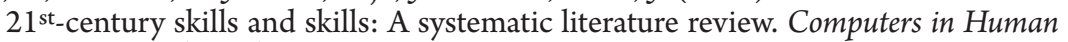
Behavior, 72 (2017), 577-588. https://www.sciencedirect.com/science/article/ pii/S0747563217301590.

Latvian Employer's Confederation (2016). LDDK survey: lack of good employees, upgrading of qualifications is important. Retrieved from: http://www.lddk.lv/ notikums/lddk-aptauja-labu-darbinieku-trukst-svariga-ir-kvalifikacijas-celsana/.

Lopez, A. R., Souto, J. E., Noblejas, M. L. A. (2019). Improving teaching capacity to increase student achievement: The key role of communication competences in Higher Education. Studies in Educational Evaluation, 60 (2019), 205-213. https://www.sciencedirect.com/science/article/pii/S0191491X18300956. 
Melton, R. (1997). Objectives, Competences and Learning Outcomes. London: Kogan Page Limited.

Orthey, F. M. (2002). Der trend zur Kompetenz. Begriffsent - wichlung und Perspektiven. Supervision, 1/2002, 7-14.

Orthey, F. M. (1999). Zeit der Modernisierung. Zugange einer Modernisierungstheorieberuflicher Bildung. Sttutgart.

Perrenoud, P. H. (2004). L'universite entre transmission de saviors et developpement de competences. Geneve: Universitate de Geneve.

Spencer, L. M., Spencer, S. M. (1993). Competence at work: models for superior performance. Wiley, pp. 372.

Sousa, M. J., Rocha, A. (2019). Digital learning: Developing skills for digital transformation of organizations. Future Generation Computer Systems, 91 (2019), 327334. https://www.sciencedirect.com/science/article/pii/S0167739X18311191.

Stabins, J. (1998). Vispārīgā pedagoǵija. 1. daļa. Izdevniecība: RaKa, Riga, p.130.

Tilla, I. (2005). Sociālkultūras mācī̌sanās organizācijas sistēma. Riga: RaKa, p. 296.

Public administration needs to change - fewer employees will not yet improve their effectiveness (2018). Retrieved from: https://lvportals.lv/viedokli/292216valsts-parvaldei-jamainas-mazaks-darbinieku-skaits-efektivitati-vel-necels-2017.

Vintisa, K. (2004). Valsts pārvaldes aktuāās problēmas. Valsts pārvaldes cilvēkresursu attīstîba. Presentation during the conference. Riga. 